\title{
Streptomyces flavogriseus HS1: Isolation and Characterization of Extracellular Proteases and Their Compatibility with Laundry Detergents
}

\author{
Sofiane Ghorbel, Maher Kammoun, Hala Soltana, Moncef Nasri, and Noomen Hmidet \\ Laboratoire de Génie Enzymatique et de Microbiologie, Ecole Nationale d'Ingénieurs de Sfax, BP 1173, 3038 Sfax, Tunisia \\ Correspondence should be addressed to Sofiane Ghorbel; so_fian@hotmail.com
}

Received 13 January 2014; Revised 22 February 2014; Accepted 5 March 2014; Published 6 April 2014

Academic Editor: Neelu Nawani

Copyright (C) 2014 Sofiane Ghorbel et al. This is an open access article distributed under the Creative Commons Attribution License, which permits unrestricted use, distribution, and reproduction in any medium, provided the original work is properly cited.

The present study describes the isolation of a new protease producing Streptomyces strain HS1 and the biochemical characterization of the secreted proteases. By sequencing of its noted 16S rDNA, HS1 strain was found to have a 100\% identity with Streptomyces flavogriseus. The highest protease production was found using FermII media. In these conditions maximum protease production $(99 \mathrm{U} / \mathrm{mL})$ was obtained after $96 \mathrm{~h}$ incubation at $30^{\circ} \mathrm{C}$ and $150 \mathrm{rpm}$. HS1 strain produced at least five proteases as revealed by zymogram technique. The enzyme preparation exhibited activity over a broad range of $\mathrm{pH}(5-11)$ and temperature $\left(25-70^{\circ} \mathrm{C}\right)$. Optimum activity was observed at a pH of 7.0 and a temperature of $50^{\circ} \mathrm{C}$. Proteolytic activity was significantly unaffected by $\mathrm{Ca}^{2+}$ and $\mathrm{Mg}^{2+}$. EDTA and PMSF highly decreased the original activity. The crude extracellular proteases showed high stability when used as a detergent additive. These properties offer an interesting potential for enzymatic hydrolysis at the industrial level.

\section{Introduction}

Actinomycetes, a Gram-positive filamentous bacteria, can degrade various macromolecules in soil [1]. Among actinomycetes, Streptomyces species are the most industrially useful because of their capacity of producing numerous secondary metabolites, particularly antibiotics. Similarly, these bacteria offer a second industrial interesting use by producing large amounts of proteolytic enzymes, with different substrate specificities [2]. The investigation of proteases does not take place only in scientific fields such as protein chemistry and protein engineering, but also in other industrial uses including cleaning detergents, leather, and food additives. Such a wide use of proteases in the industrial field shows their importance especially that they represent around $60 \%$ of the total enzyme market [3]. Unlike proteases from other bacteria which have been extensively characterized, proteases from actinomycetes did not receive a similar attention [4]. Still, their ability to produce a variety of enzymes may be an attractive phenomenon of these prokaryotes.

The composition of the protease complexes secreted by Streptomyces is determined by the taxonomic position of the producers [5-8]. The potential use of Streptomyces for producing proteases is justified by their ability to release the proteins into extracellular media. Such a capability is generally regarded as safe (GRAS) with food and drug administration. Streptomyces spp. that produce proteases include S. clavuligerus, S. griseus, S. rimouses, S. thermoviolaceus, and S. thermovulgaris [7]. Some of these proteases, like the serine proteases of Streptomyces griseus $[8,9]$ and Streptomyces fradiae [10], have been characterized structurally and enzymatically. There have also been many descriptions of isolation and partial characterization of alkaline protease activities from other members of the genus Streptomyces like Streptomyces clavuligerus, Streptomyces gulbargensis, Streptomyces viridifaceins, and Streptomyces sp. [11-13].

Present study describes the isolation of a multiple protease producing Streptomyces flavogriseus HS1 strain, isolated from a Tunisian soil. We report the biochemical characterization of the crude enzyme for evaluation of its biotechnological potential as detergent additive.

\section{Material and Methods}

2.1. Isolation of the Actinomycete Strain. The isolation of the Actinomycete strains from a soil sample was done by serial 
dilution plate technique on ISP4 agar media containing (g/L) starch 10, casein $0.3, \mathrm{KNO}_{3} 2, \mathrm{NaCl} 2, \mathrm{~K}_{2} \mathrm{HPO}_{4} 2$, $\mathrm{MgSO}_{4} \cdot 7 \mathrm{H}_{2} \mathrm{O} 0.05, \mathrm{CaCO}_{3} 0.02, \mathrm{FeSO}_{4} \cdot 7 \mathrm{H}_{2} \mathrm{O} 0.01$, and 15 agar [14].

2.2. Identification of HS1 Strain. The $16 \mathrm{~S}$ rRNA gene of the HS1 strain was amplified by PCR using the following primers: $\mathrm{F}$ (forward), $5^{\prime}$-CCGAATTCGTCGACAACAGAGTTTGATCCTGGCTCAG- $3^{\prime}$ and R (reverse), $5^{\prime}$-CCCGGGATCCAAGCTTAAGGAGGTGATCCAGCC-3'. The PCR mixture contained $30 \mathrm{pmol}$ of primers, $20 \mathrm{pmol}$ of each deoxynucleoside triphosphate, polymerisation buffer, and $5 \mathrm{U}$ Taq polymerase. The PCR program involved 35 cycles of denaturing at $94^{\circ} \mathrm{C}$ for $1 \mathrm{~min}$, primer annealing at $55^{\circ} \mathrm{C}$ for $1 \mathrm{~min}$, and extension at $72^{\circ} \mathrm{C}$ for $90 \mathrm{~s}$. The sequencing was performed three times using the DNA sequencer ABI PRISM 3100/3100-Avant Genetic Analyser (CA, USA). 16S rDNA sequence was searched for similarities to known sequences in the GenBank database (National Center for Biotechnology Information, National Library of Medicine) using the BLAST search program. The sequence was aligned with those of the reference strains using ClustalW [15]. A phylogenetic tree was constructed by the neighbour-joining method [16].

2.3. Determination of Protease Activity. Measuring of the protease activity was done as described by Kembhavi et al. [17], using casein as substrate $1 \%(\mathrm{w} / \mathrm{v})$ in $100 \mathrm{mM}$ Tris- $\mathrm{HCl}$ buffer, $\mathrm{pH}$ 7.0. The mixture was incubated for $15 \mathrm{~min}$ at $50^{\circ} \mathrm{C}$ and the reaction was stopped by addition of $0.5 \mathrm{~mL} 20 \%(\mathrm{w} / \mathrm{v})$ TCA (trichloroacetic acid). The mixture was left at room temperature for 10 minutes and then centrifuged at $10000 \mathrm{~g}$ for 15 minutes to remove the precipitate. The absorbance of the soluble TCA peptides was recorded at $280 \mathrm{~nm}$. One unit of protease activity was defined as the amount of enzyme required to liberate $1 \mu \mathrm{g}$ of tyrosine per minute under the experimental conditions used. All measurements were carried out in triplicate.

2.4. Protease Production. The proteolytic isolates were cultured in three different liquid medium: FermII media: (g/L) dextrin 20, tryptone $10, \mathrm{KH}_{2} \mathrm{PO}_{4}$ 1.0, $\mathrm{K}_{2} \mathrm{HPO}_{4} 3.4$, $\mathrm{MgSO}_{4} \cdot 7 \mathrm{H}_{2} \mathrm{O} 0.3, \mathrm{FeSO}_{4} \cdot 7 \mathrm{H}_{2} \mathrm{O} 0.01, \mathrm{ZnCl}_{2} 0.1, \mathrm{CuSO}_{4} \cdot 7 \mathrm{H}_{2} \mathrm{O}$ 0.01, $\mathrm{MgCl}_{2} \cdot 4 \mathrm{H}_{2} \mathrm{O} 0.003, \mathrm{CaCl}_{2} 0.01, \mathrm{NaCl} 0.03, \mathrm{pH} 7.0$ [18], gelatin containing media: $(\mathrm{g} / \mathrm{L})$ : gelatin, 10 ; peptone, 5 ; yeast extract, 5; $\mathrm{NaCl}, 50$; and $\mathrm{pH}$ 9, and liquid ISP4 media [14].

A $1 \mathrm{~mL}$ spore suspension $\left(10^{4}\right.$ to $10^{6}$ spores $\left./ \mathrm{mL}\right)$ was added to a $250 \mathrm{~mL}$ Erlenmeyer flask containing $100 \mathrm{~mL}$ of liquid media [14], and the flasks were incubated at $30^{\circ} \mathrm{C}$ and $150 \mathrm{rpm}$ for $96 \mathrm{~h}$. The culture medium was centrifuged at $5000 \mathrm{rpm}$ to remove mycelia and medium debris, and the supernatant was used as a crude enzyme preparation.

2.5. Characterization of Proteases. Zymography was performed on NativePAGE according to the method of GarciaCarreno et al. [19]. After electrophoresis, the gel was submerged in $1 \%(\mathrm{w} / \mathrm{v})$ casein in $100 \mathrm{mM}$ glycine- $\mathrm{NaOH}$ buffer, $\mathrm{pH} 7.0$, and incubated at $50^{\circ} \mathrm{C}$ for $20 \mathrm{~min}$. After washing, the gel was stained with Coomassie Brilliant Blue R-250 and destained with $5 \%$ ethanol-7.5\% acetic acid. A clear zone appeared on the blue background of the gel which indicated the presence of protease activity.

2.6. Effect of Temperature and $\mathrm{pH}$ on Protease Activity and Stability. To investigate the temperature effect, the protease assay was performed at different temperatures between 20 and $80^{\circ} \mathrm{C}$, using casein as substrate for $10 \mathrm{~min}$ at $\mathrm{pH} \mathrm{7.0.}$ For thermal stability, the enzyme was incubated at different temperatures for $60 \mathrm{~min}$. Aliquots were withdrawn at the designed time intervals to test the remaining activity. The residual activity was assayed at $\mathrm{pH} 7.0$ and $50^{\circ} \mathrm{C}$ for $10 \mathrm{~min}$. The nonheated enzyme was considered as control $(100 \%$ activity).

Protease activity was assayed over the $\mathrm{pH}$ range 5.0-12.0 at $50^{\circ} \mathrm{C}$ for $10 \mathrm{~min}$, using casein as a substrate. The effect of $\mathrm{pH}$ on enzyme stability was evaluated by measuring the residual enzyme activity after incubation at various $\mathrm{pH}$ for $60 \mathrm{~min}$ at $25^{\circ} \mathrm{C}$. The following buffer systems were used: $100 \mathrm{mM}$ glycine- $\mathrm{HCl}, \mathrm{pH} 4.0$ and $5.0 ; 100 \mathrm{mM}$ sodium acetate, $\mathrm{pH}$ $6.0 ; 100 \mathrm{mM}$ phosphate-buffer, $\mathrm{pH} 7.0 ; 100 \mathrm{mM}$ Tris- $\mathrm{HCl}, \mathrm{pH}$ 8.0; $100 \mathrm{mM}$ glycine- $\mathrm{NaOH}, \mathrm{pH} 9.0$ and 10 ; and $100 \mathrm{mM}$ $\mathrm{Na}_{2} \mathrm{HPO}_{4} \cdot \mathrm{NaOH}, \mathrm{pH} 12.0$.

2.7. Effect of Metal Ions and Other Chemicals on Protease Activity and Stability. The effects of different monovalent $\left(\mathrm{Na}^{+}\right.$or $\left.\mathrm{K}^{+}\right)$or divalent $\left(\mathrm{Fe}^{2+}, \mathrm{Mn}^{2+}, \mathrm{Zn}^{2+}, \mathrm{Cu}^{2+}, \mathrm{Ba}^{2+}, \mathrm{Mg}^{2+}\right.$, or $\mathrm{Hg}^{2+}$ ) metal ions, at a concentration of $5 \mathrm{mM}$, on protease activity were investigated by adding them to the reaction mixture. The activity in the absence of any additives was taken as $100 \%$.

The effects of enzyme inhibitors on protease activity were studied using PMSF and EDTA. The crude enzyme was preincubated with each inhibitor for $30 \mathrm{~min}$ at $25^{\circ} \mathrm{C}$, and then the remaining enzyme activity was estimated using casein as a substrate. The activity in the absence of inhibitors was taken as $100 \%$. The effects of some surfactants (Triton X-100, Tween 80 , and SDS) and oxidizing agents (sodium perborate) on enzyme stability were studied by preincubating the crude enzyme for $1 \mathrm{~h}$ at $25^{\circ} \mathrm{C}$. The residual activity was measured at $\mathrm{pH} 7.0$ and $50^{\circ} \mathrm{C}$. The activity of the enzyme without any additive was taken as $100 \%$.

2.8. Detergent Compatibility. The compatibility of the HS1 extracellular proteases with commercial laundry detergents was studied using Ariel (Procter and Gamble, Switzerland), Newdet (Sodet, Tunisia), and Dixan (Henkel, Spain) as solid detergents. The endogenous proteases contained in these detergents were inactivated by heating the diluted detergents for $1 \mathrm{~h}$ at $65^{\circ} \mathrm{C}$ prior to the addition of the enzyme preparation. The extracellular proteases of Streptomyces flavogriseus HS1 were incubated with different diluted detergents (1/100) for $1 \mathrm{~h}$ at $30^{\circ} \mathrm{C}, 40^{\circ} \mathrm{C}$, and $50^{\circ} \mathrm{C}$ and then the remaining activities were determined under the standard assay conditions. The enzyme activity of a control, without detergent, incubated under similar conditions, was taken as $100 \%$.

2.9. Statistical Analysis. Statistical analyses were performed with Statgraphics ver. 5.1, professional edition (Manugistics 
TABLE 1: Effect of various culture media on the production of extracellular proteases from Streptomyces flavogriseus HS1.

\begin{tabular}{lc}
\hline Medium & Proteolytic activity $(\mathrm{U} / \mathrm{mL})$ \\
\hline FermII & 98 \\
Gelatin based medium & 4.7 \\
ISP4 & 51.8 \\
\hline
\end{tabular}

The activity of the proteases was determined at $50^{\circ} \mathrm{C}$ and $\mathrm{pH} 7.0$ after $96 \mathrm{~h}$ of culture.

Corp., USA) using ANOVA analysis. Differences were considered significant at $P<0.05$. Results represent the means of at least two determination carried out in duplicate. The difference between values did not exceed $5 \%$.

\section{Results and Discussion}

3.1. Isolation of the Actinomycete Strain. Samples were taken from an organic rich soil in Sfax city (Tunisia). Isolation of the actinomycete strains was obtained after $96 \mathrm{~h}$ of incubation at $30^{\circ} \mathrm{C}$. One isolate was selected for further studies because of its important extracellular proteases secretion and named HS1 strain (Figure 1). HS1 strain was confirmed as belonging to the genus Streptomyces since it possessed nonfragmented substrate mycelia, aerial hyphae, and smooth spores organized in straight chains. Analysis of the 16S rRNA gene sequence of this strain showed a high similarity (100\%) with Streptomyces flavogriseus (Figure 2).

Streptomyces flavogriseus was well known to produce several enzymes such as cellulose, xylanase, and glucose isomerase [19-21], but no data was found describing extracellular proteases.

3.2. Protease Production. Three liquid culture media optimized for the production of extracellular proteases in Streptomyces were tested, among them are FermII [18], ISP4 [14], and gelatin based media (this study). In the light of this experiment, FermII was found to be the best medium for the production of Streptomyces flavogriseus HS1 extracellular proteases (Table 1). The fermentation time course for protease production by Streptomyces flavogriseus HS1 (data not shown) indicates that the maximum protease activity $(99 \mathrm{U} / \mathrm{mL})$ was obtained after $96 \mathrm{~h}$ of cultivation, when cells were in the stationary phase, and its production was not growth associated. Similar results were obtained by Gibb and Strohl [22], who observed that the maximum protease production by Streptomyces peucetius occurred after $100 \mathrm{~h}$ of cultivation at the stationary phase growth. This period was shorter than that of the well-studied Streptomyces (e.g., Streptomyces moderatus required $120 \mathrm{~h}$ of cultivation for maximum protease production [6]). However, Dastager et al. [13] showed that the protease activity measured in the cell-free supernatant fluid of Streptomyces gulbargensis sp. Nov. was maximum $(121.8 \mathrm{U} / \mathrm{mL})$ after $48 \mathrm{~h}$ of growth.

3.3. Zymogram. To give more information about the diversity of extracellular proteases secreted by HS1 strain, zymogram analysis was done as described in the "Material and Methods"

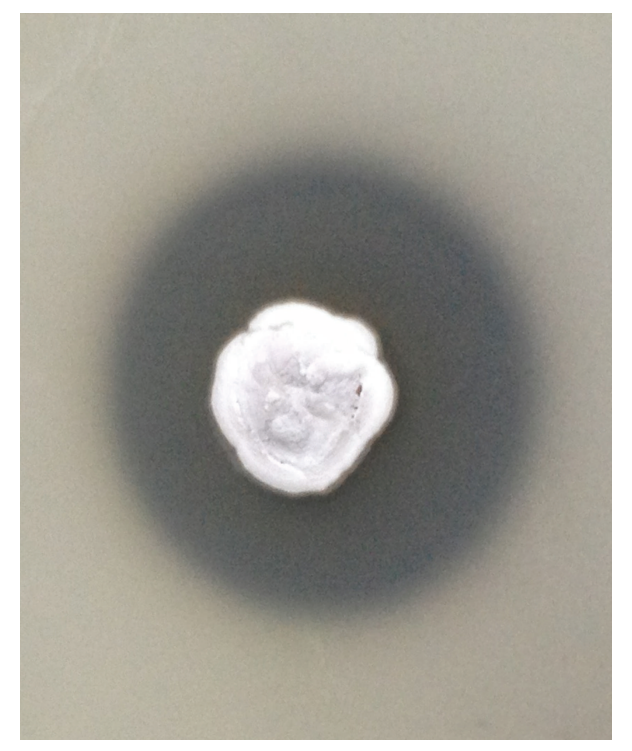

FIGURE 1: Plate assay showing the zone of proteolytic activity by protease-producing Streptomyces flavogriseus HS1 strain.

section. As shown in Figure 3, proteolytic activity profiles of cell-free enzymatic preparation of Streptomyces flavogriseus HS1 showed at least five major proteases. This is a common feature for the streptomycetes $[6,23]$. However, the nature and characteristics of the enzymes of protease complex derived from streptomycetes have not been widely studied [6]. All the thermophilic bacterial extracellular proteases so far reported are, interestingly, serine or neutral metalloproteases [24].

3.4. Effect of the pH on Activity and Stability of Streptomyces flavogriseus HS1 Extracellular Proteases. The $\mathrm{pH}$ profile of protease activity from Streptomyces flavogriseus HS1 is shown in Figure 4(a). The crude enzyme was highly active between $\mathrm{pH} 6.0$ and 8.0, having an optimum around $\mathrm{pH}$ 7.0. The relative activities at pH 6.0 and 8.0 were about 65 to $75 \%$. Similar results were described for several Streptomyces strains in the literature with optimum $\mathrm{pH}$ range being between 6.0 and 12.0 [25]. The optimum $\mathrm{pH}$ activity of Streptomyces flavogriseus proteases was similar to that from other Streptomyces species, such as Streptomyces griseus pronase [26]. Therefore, this activity was lower than that of other Streptomyces described proteases, showing maximum activity at $\mathrm{pH} 8.0$ like Streptomyces sp. DP2 [27] and Streptomyces sp. CN902 [28]. The $\mathrm{pH}$ stability test showed that the crude proteases were highly stable over a broad $\mathrm{pH}$ range, maintaining more than $70 \%$ of its original activity between pH 5.0 and 9.0 (Figure 4(b)).

3.5. Effect of Temperature on the Activity and Stability of Streptomyces flavogriseus HS1 Extracellular Proteases. The temperature profile of protease activity from Streptomyces flavogriseus HS1 is presented in Figure 5(a). The HS1 crude extract was active at temperatures from 30 to $70^{\circ} \mathrm{C}$ and had an optimum at $50^{\circ} \mathrm{C}$, while activity decreased rapidly above $70^{\circ} \mathrm{C}$. The relative activities at 40 and $60^{\circ} \mathrm{C}$ were about $63 \%$ 


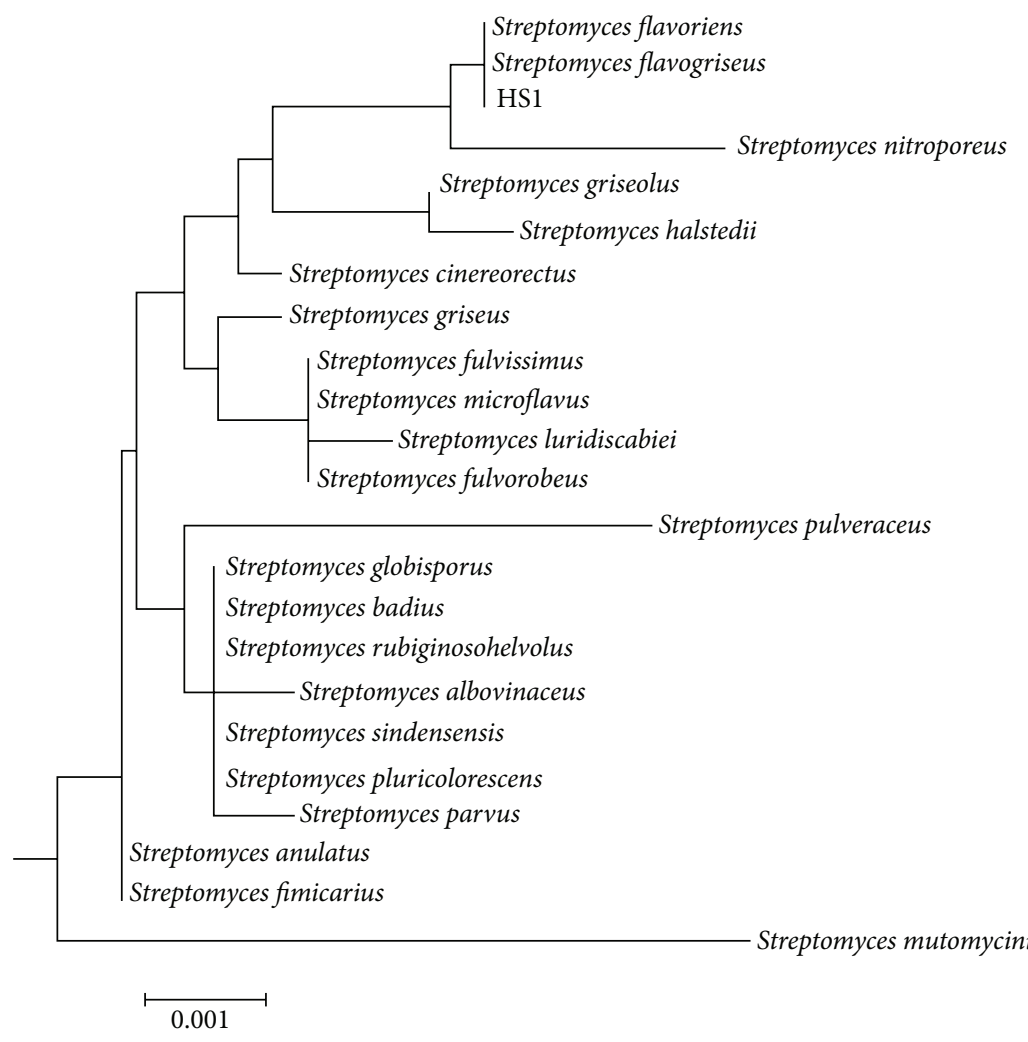

FIgURE 2: Dendrogram showing the relationships between Streptomyces flavogriseus HS1 and other Streptomyces species. Topology was inferred using the neighbour-joining method.

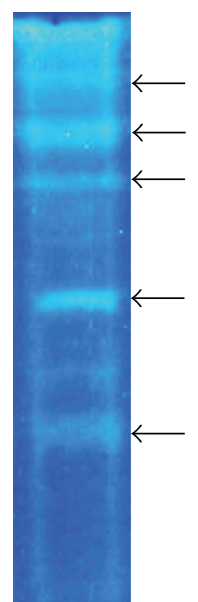

Figure 3: Zymography analysis of Streptomyces flavogriseus HS1 crude extracellular proteases.

and $60 \%$, respectively. Several actinomycete thermophilic proteases, with high activity at $70^{\circ} \mathrm{C}$, have been reported for Thermoactinomyces vulgaris and Nocardiopsis dassonvillei, S. corchorusii [23], S. megasporus [29], S. thermovulgaris [4], and $S$. thermoviolaceus [7]. Above $60^{\circ} \mathrm{C}$, protease activity from Streptomyces flavogriseus HS1 rapidly fell, as shown for proteases of Streptomyces spp. and other bacteria.
The thermal stability profile of the crude enzyme showed a high stability at temperatures below $40^{\circ} \mathrm{C}$ but was inactivated at higher temperatures (Figure 5(b)). After $45 \mathrm{~min}$ of incubation at $60^{\circ} \mathrm{C}, 78 \%$ of the initial activity was lost. Streptomyces flavogriseus HS1 proteases were stable at 40 and $50^{\circ} \mathrm{C}$ after $1 \mathrm{~h}$ incubation. At low temperatures $\left(-20\right.$ and $\left.4^{\circ} \mathrm{C}\right)$, the crude enzyme preparation retained $75 \%$ of its activity after 2 months. El-Raheem et al. [23] observed that for alkaline proteases from a strain of $S$. corchorusii, activity did not decrease after storage at $-20^{\circ} \mathrm{C}$ for one year, at $\mathrm{pH}$ values between 4.0 and 12.0, and repeated freezing and thawing.

3.6. Effects of Metal Ions. The effects of some metal ions, at a concentration of $5 \mathrm{mM}$, on the activity of Streptomyces flavogriseus HS1 crude enzyme were studied at pH 7.0 and $50^{\circ} \mathrm{C}$ by the addition of the respective cations to the reaction mixture (Table 2). The $\mathrm{Ca}^{2+}, \mathrm{Mg}^{2+}$, and $\mathrm{Na}^{+}$were shown to have no effect on the protease activity. The latter was slightly affected by $\mathrm{Ba}^{2+}$ and $\mathrm{K}^{+}$and it retains about $79.1 \%$ and $66.6 \%$ of its activity, respectively. The $\mathrm{Hg}^{2+}, \mathrm{Cu}^{2+}$, and $\mathrm{Zn}^{2+}$ greatly affected the enzymatic activity till the total inhibition. Reduction in protease activity of Streptomyces spp. has been previously observed $[30,31]$, especially for $\mathrm{Cu}^{2+}$, probably as a result of the denaturing action of copper [31] and the chelating effect of EDTA. Proteases from Streptomyces spp. and $\mathrm{N}$. dassonvillei were also stimulated by $\mathrm{Mg}^{2+}, \mathrm{Mn}^{2+}$, $\mathrm{Ca}^{2+}$, and $\mathrm{Zn}^{2+}$ [30], whereas cation-requiring proteases 


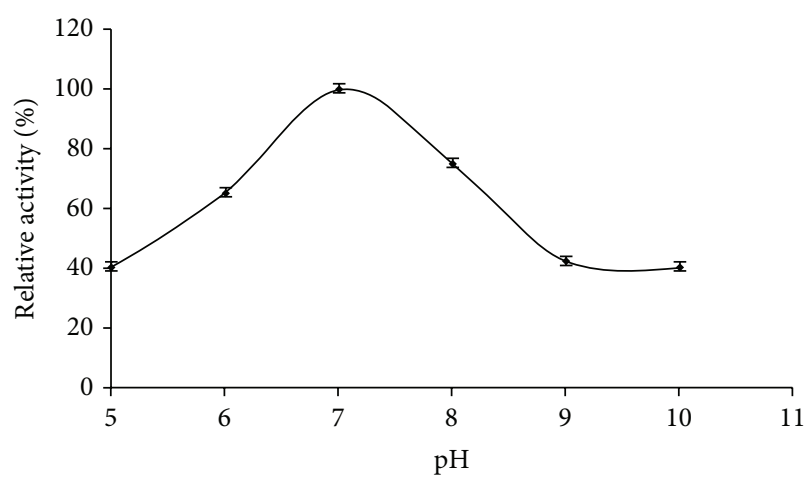

(a)

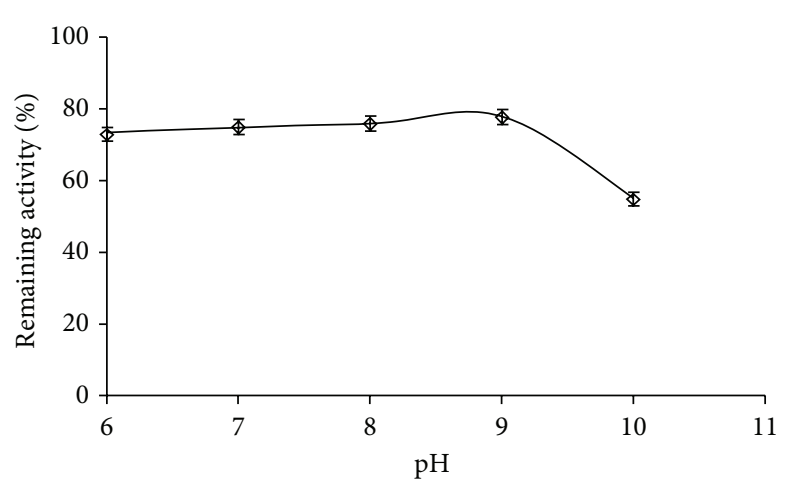

(b)

FIGURE 4: Effect of $\mathrm{pH}$ on activity (a) and stability (b) of the crude protease from Streptomyces flavogriseus HS1. The protease activity was assayed in the $\mathrm{pH}$ range of 5.0-12.0 using buffers of different $\mathrm{pH}$ values at $50^{\circ} \mathrm{C}$. The maximum activity obtained from $\mathrm{pH} 7.0 \mathrm{was}$ considered as $100 \%$ activity. The $\mathrm{pH}$ stability of the Streptomyces flavogriseus HS1 crude enzyme was assayed in the rage of $5.0-12.0$ and determined by incubating the crude protease in different buffers for $1 \mathrm{~h}$ at $25^{\circ} \mathrm{C}$ and the residual activity was determined at $\mathrm{pH} 7.0$ and $50^{\circ} \mathrm{C}$. The proteolytic activity before incubation was taken as $100 \%$.

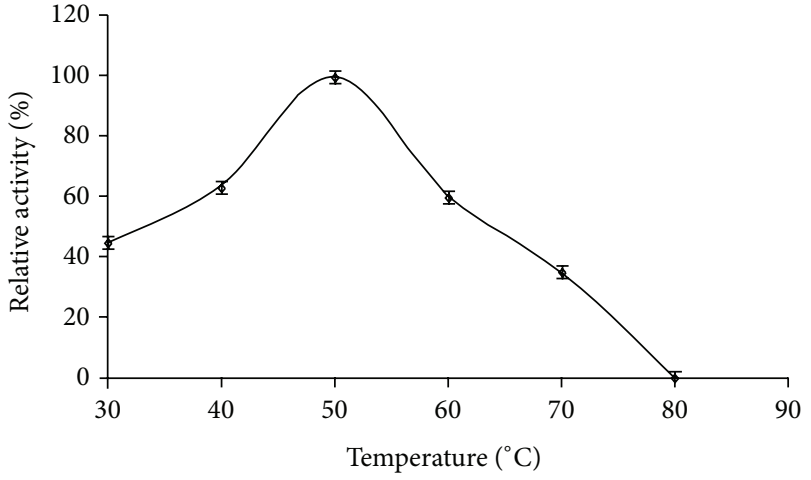

(a)

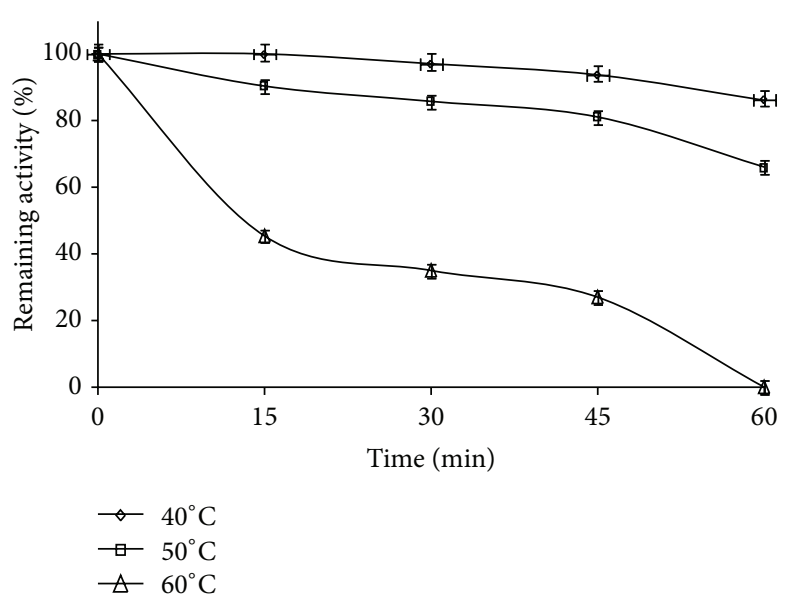

(b)

FIGURE 5: Effect of temperature on activity (a) and stability (b) of the crude protease from Streptomyces flavogriseus HS1. The temperature profile was determined by assaying protease activity at temperatures between 30 and $80^{\circ} \mathrm{C}$. The activity of the crude enzyme at $50^{\circ} \mathrm{C}$ was taken as $100 \%$. The temperature stability was determined by incubating Streptomyces flavogriseus HS1 crude enzyme at temperatures from 40 to $60^{\circ} \mathrm{C}$ for $1 \mathrm{~h}$. The residual proteolytic activity was determined at regular intervals under standard assay conditions. The original activity before preincubation was taken as $100 \%$.

from streptomycetes have also been reported [32]. However, Streptomyces sp. 594 protease stability was enhanced only by $\mathrm{Ca}^{2+}$ and $\mathrm{Ba}^{2+}[33]$. It was shown that the $\mathrm{Ca}^{2+}$ ions are important for catalysis. James et al. [7] suggested that most probably they stabilize the protein through specific or nonspecific binding sites and may also allow for additional bonding within the enzyme molecule, preventing unfolding at higher temperatures, as has been demonstrated for protease from thermophilic bacteria, mainly thermolysin.

3.7. Effects of Enzyme Inhibitors on Protease Activity. Proteases can be classified by their sensitivity to various inhibitors [34]. In order to confirm the nature of the extracellular proteases, the effects of different enzyme inhibitors, such as chelating agent and a specific group of reagents, on the protease activity were investigated (Table 3 ). The crude proteolytic preparation was strongly inhibited by the serine protease inhibitor (PMSF) indicating that the HS1 crude extract contained serine proteases. In addition, the enzymatic extract was also inhibited by the chelating agent EDTA $(5 \mathrm{mM})$, with $77 \%$ of its original activity being lost, indicating the importance of ions in enzyme stabilization. These findings are in line with several earlier reports showing that active structure of serine proteases contains $\mathrm{Ca}^{2+}$ binding site(s) and the removal of $\mathrm{Ca}^{2+}$ from the strong binding site is associated with a significant reduction in thermal stability [35]. From this result, HS1 can contain serine metalloproteases since the crude enzyme is strongly inhibited by both PMSF and EDTA. 
TABLE 2: Effect of various metal ions ( $5 \mathrm{mM})$ on the activity of crude enzyme from Streptomyces flavogriseus HS1.

\begin{tabular}{|c|c|c|c|c|c|c|c|c|c|c|}
\hline Ions (5 mM) & None & $\mathrm{Ca}^{2+}$ & $\mathrm{Mg}^{2+}$ & $\mathrm{Fe}^{2+}$ & $\mathrm{Mn}^{2+}$ & $\mathrm{Cu}^{2+}$ & $\mathrm{Ba}^{2+}$ & $\mathrm{Hg}^{2+}$ & $\mathrm{Na}^{+}$ & $\mathrm{K}^{+}$ \\
\hline Relative activity (\%) & 100 & 100 & 100 & 71 & 100 & 0 & 79 & 0 & 100 & 67 \\
\hline
\end{tabular}

The activity of the proteases was determined by incubating the enzyme in the presence of various metal ions for $10 \mathrm{~min}$ at $50^{\circ} \mathrm{C}$ and $\mathrm{pH} 7.0$.

TABLE 3: Effect of various enzyme inhibitors $(5 \mathrm{mM})$ on the activity of extracellular proteases from Streptomyces flavogriseus HS1.

\begin{tabular}{lc}
\hline Inhibitors & Remaining activity (\%) \\
\hline None & 100 \\
PMSF & 5 \\
EDTA & 23 \\
\hline
\end{tabular}

The secreted proteases from Streptomyces flavogriseus HS1 were preincubated with various enzyme inhibitors for $30 \mathrm{~min}$ at room temperature and the remaining activity was determined at $\mathrm{pH} 7.0$ and $50^{\circ} \mathrm{C}$. Crude protease activity measured in the absence of any inhibitor was taken as $100 \%$.

TABLE 4: Stability of the Streptomyces flavogriseus HS1 extracellular proteases in the presence of various surfactants and oxidizing agents.

\begin{tabular}{lcc}
\hline Detergents & Concentrations (\%) & Remaining activity (\%) \\
\hline \multirow{2}{*}{ Triton X-100 } & $1 \%$ & 61.4 \\
& $5 \%$ & 40.5 \\
\hline \multirow{2}{*}{ Tween 80} & $1 \%$ & 71.4 \\
& $5 \%$ & 40.5 \\
\multirow{2}{*}{ Tween 20 } & $1 \%$ & 70.2 \\
& $5 \%$ & 37.8 \\
\hline \multirow{2}{*}{ SDS } & $0.1 \%$ & 18.9 \\
& $0.5 \%$ & 0 \\
\multirow{2}{*}{ Sodium perborate } & $0.1 \%$ & 64.1 \\
& $1 \%$ & 39.8 \\
\hline \multirow{2}{*}{$\mathrm{H}_{2} \mathrm{O}_{2}$} & $0.1 \%$ & 61.4 \\
\end{tabular}

The crude extracellular proteases were incubated with different surfactants and oxidizing agents for $1 \mathrm{~h}$ at $25^{\circ} \mathrm{C}$ and the remaining activity was measured under standard conditions. The activity is expressed as a percentage of the activity level in the absence of additives.

\subsection{Effects of Oxidizing Agents and Surfactants on Protease} Stability. In order to be effective during washing, a good detergent protease must be compatible and stable with all commonly used detergent compounds such as surfactants, oxidizing agents, and other additives, which might be present in the detergent formulation $[29,30]$. HS1 protease extract was preincubated $60 \mathrm{~min}$ at $25^{\circ} \mathrm{C}$ in the presence of SDS, Tween 20 and 80 , and Triton X-100 and the residual activities were assayed at $\mathrm{pH} 7.0$ and $50^{\circ} \mathrm{C}$ (Table 4). Interestingly, the Streptomyces flavogriseus HS1 proteases were less stable against the strong anionic surfactant (SDS) and retained only $19 \%$ of its activity in the presence of $0.1 \%(\mathrm{w} / \mathrm{v})$ SDS. However, HS1 protease activity was little influenced by oxidizing agents and retained $64.1 \%$ and $39.8 \%$ of its activity after incubation for $1 \mathrm{~h}$ at $25^{\circ} \mathrm{C}$ in the presence of $0.1 \%$ and $1 \%$ sodium perborate, respectively (Table 4 ). The stability of the enzyme in the presence of oxidizing agents is a very important characteristic for its eventual use in detergent formulations.

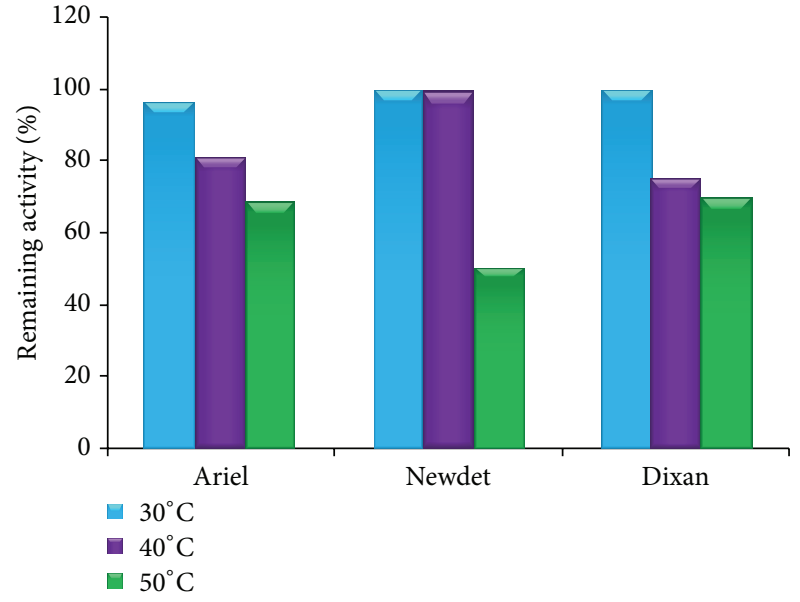

FIgURE 6: Stability of crude protease from Streptomyces flavogriseus HS1 in the presence of various commercial solid detergents. The enzyme at $100 \mathrm{U} / \mathrm{mL}$ was incubated $1 \mathrm{~h}$ at $30^{\circ} \mathrm{C}, 40^{\circ} \mathrm{C}$, and $50^{\circ} \mathrm{C}$ in the presence of solid detergents. The remaining activities were determined at $\mathrm{pH} 7.0$ and $50^{\circ} \mathrm{C}$ using casein as a substrate. Enzyme activity of control sample without any detergent, incubated under the similar conditions, was taken as $100 \%$.

Important commercial detergent proteases like Subtilisin Carlsberg, Subtilisin BPN ${ }^{\prime}$, Alcalase, Esparase, and Savirase are stable in the presence of various detergent components. However, most are unstable in the presence of oxidant agents, such as hydrogen peroxide [36].

3.9. Stability of the Streptomyces flavogriseus HS1 Proteases with Commercial Solid Detergents. The high activity and stability of the Streptomyces flavogriseus HS1 proteases in the $\mathrm{pH}$ range 5.0-10.0 and their relative stability towards surfactants and oxidizing agents are very useful for its eventual application as a detergent additive. To check the compatibility of the proteases with solid detergents, the crude enzyme was preincubated in the presence of various commercial laundry solid detergents for $1 \mathrm{~h}$ at different temperatures $(30,40$, and $50^{\circ} \mathrm{C}$ ) (Figure 6). The data showed that the proteases were stable in Ariel and Dixan, retaining 70\% of their activity at $50^{\circ} \mathrm{C}$. The obtained results clearly indicated that the performance of enzymes in detergents depends on number of factors, including the detergents compounds since the proteolytic stability of HS1 proteases varied with each laundry tested detergent.

Singh et al. [37] reported that the alkaline protease from Bacillus sp. SSR1 retained $37 \%$ of its initial activity after $1 \mathrm{~h}$ incubation at $40^{\circ} \mathrm{C}$ in the presence of Ariel at a concentration of $5 \mathrm{mg} / \mathrm{mL}$. Alkaline protease from Conidiobolus coronatus retained only $16 \%$ activity in Revel, $11.4 \%$ activity in Ariel, 
and $6.6 \%$ activity in Wheel at $50^{\circ} \mathrm{C}$, in the presence of $25 \mathrm{mM}$ $\mathrm{CaCl}_{2}[38]$.

\section{Conclusion}

This work describes the isolation of an actinomycete strain identified as Streptomyces flavogriseus HS1, which produces at least five proteases as described by zymogram technique. Crude protease was shown to have optimum activity at $\mathrm{pH} 7$ and $50^{\circ} \mathrm{C}$. The crude enzyme has a good stability toward the oxidizing agents and was found to be useful as a detergent additive.

\section{Conflict of Interests}

The authors declare that there is no conflict of interests regarding the publication of this paper.

\section{Acknowledgment}

This work was funded by the Ministry of Higher Education and Scientific Research, Tunisia.

\section{References}

[1] H. Tsujibo, K. Miyamoto, T. Hasegawa, and Y. Inamori, "Purification and characterization of two types of alkaline serine proteases produced by an alkalophilic actinomycete," Journal of Applied Bacteriology, vol. 69, no. 4, pp. 520-529, 1990.

[2] W. Peczynska-Czoch, "Actinomycete enzymes," in Actinomycetes in Biotechnology, pp. 219-283, Academic Press, London, 1988.

[3] M. B. Rao, A. M. Tanksale, M. S. Ghatge, and V. V. Deshpande, "Molecular and biotechnological aspects of microbial proteases," Microbiology and Molecular Biology Reviews, vol. 62, no. 3, pp. 597-635, 1998.

[4] K. H. Yeoman and C. Edwards, "Protease production by Streptomyces thermovulgaris grown on rapemeal-derived media," Journal of Applied Bacteriology, vol. 77, no. 3, pp. 264-270, 1994.

[5] M. Pokorny, L. Vitale, V. Turk, M. Renko, and J. Žuvanić, “Streptomyces rimosus extracellular proteases-1. Characterization and evaluation of various crude preparations," European Journal of Applied Microbiology and Biotechnology, vol. 8, no. 1-2, pp. 8190, 1979.

[6] S. Chandrasekaran and S. C. Dhar, "Multiple proteases from Streptomyces moderatus. II. Physicochemical and enzymatic properties of the extracellular proteases," Archives of Biochemistry and Biophysics, vol. 257, no. 2, pp. 402-408, 1987.

[7] P. D. A. James, M. Iqbal, C. Edwards, and P. G. G. Miller, "Extracellular protease activity in antibiotic-producing Streptomyces thermoviolaceus," Current Microbiology, vol. 22, no. 6, pp. 377382, 1991.

[8] T. Muro, T. Murakami, Y. Tominaga, T. Tokuyama, and S. Okada, "Purification and some properties of protease I having transfer action from Streptomyces griseus var. alcalophilus," Agricultural and Biological Chemistry, vol. 55, no. 2, pp. 307-314, 1991.

[9] V. K. Antonov, Chemistry of Proteolysis, Springer, New York, NY, USA, 1993.
[10] K. Kitadokoro, H. Tsuzuki, E. Nakamura, T. Sato, and H. Teraoka, "Purification, characterization, primary structure, crystallization and preliminary crystallographic study of a serine proteinase from Streptomyces fradiae ATCC 14544," European Journal of Biochemistry, vol. 220, no. 1, pp. 55-61, 1994.

[11] J. Thumar and S. P. Singh, "Two-step purification of a highly thermostable alkaline protease from salt-tolerant alkaliphilic Streptomyces clavuligerus strain Mit-1," Journal of Chromatography B: Analytical Technologies in the Biomedical and Life Sciences, vol. 854, no. 1-2, pp. 198-203, 2007.

[12] A. S. Rana, I. S. Rana, and L. Yadav, "Alkaline proteases from Streptomyces viridifaceins and its application with detergents," Advanced Biotechnology, vol. 10, no. 4, pp. 10-14, 2010.

[13] S. G. Dastager, A. Dayanand, W.-J. Li et al., "Proteolytic activity from an alkali-thermotolerant Streptomyces gulbargensis sp. nov," Current Microbiology, vol. 57, no. 6, pp. 638-642, 2008.

[14] M. K. Kharel, M. D. Shepherd, S. E. Nybo, M. L. Smith, M. A. Bosserman, and J. Rohr, "Isolation of Streptomyces species from soil," Current Protocols in Microbiology, no. 19, Article ID 10E.4, 2010.

[15] J. D. Thompson, D. G. Higgins, and T. J. Gibson, "CLUSTAL $\mathrm{W}$ : improving the sensitivity of progressive multiple sequence alignment through sequence weighting, position-specific gap penalties and weight matrix choice," Nucleic Acids Research, vol. 22, no. 22, pp. 4673-4680, 1994.

[16] N. Saitou and M. Nei, "The neighbor-joining method: a new method for reconstructing phylogenetic trees," Molecular Biology and Evolution, vol. 4, no. 4, pp. 406-425, 1987.

[17] A. A. Kembhavi, A. Kulkarni, and A. Pant, "Salt-tolerant and thermostable alkaline protease from Bacillus subtilis NCIM No. 64," Applied Biochemistry and Biotechnology, vol. 38, no. 1-2, pp. 83-92, 1993.

[18] W.-J. Chi, J.-H. Song, E. A. Oh et al., "Medium optimization and application of affinity column chromatography for trypsin production from recombinant Streptomyces griseus," Journal of Microbiology and Biotechnology, vol. 19, no. 10, pp. 1191-1196, 2009.

[19] F. L. Garcia-Carreno, L. E. Dimes, and N. F. Haard, "Substrategel electrophoresis for composition and molecular weight of proteinases or proteinaceous proteinase inhibitors," Analytical Biochemistry, vol. 214, no. 1, pp. 65-69, 1993.

[20] W. P. Chen, A. W. Anderson, and Y. W. Han, "Extraction of glucose isomerase from Streptomyces flavogriseus," Applied and Environmental Microbiology, vol. 37, no. 4, pp. 785-787, 1979.

[21] R. Srivastava, S. S. Ali, and B. S. Srivastava, "Cloning of xylanase gene of Streptomyces flavogriseus in Escherichia coli and bacteriophage $\lambda$-induced lysis for the release of cloned enzyme," FEMS Microbiology Letters, vol. 78, no. 2-3, pp. 201205, 1991.

[22] G. D. Gibb and W. R. Strohl, "Physiological regulation of protease activity in Streptomyces peucetius," Canadian Journal of Microbiology, vol. 34, no. 2, pp. 187-190, 1988.

[23] A. El-Raheem, R. El-Shanshoury, M. A. El-Sayed, R. H. Sammour, and W. A. El-Shouny, "Purification and partial characterization of two extracellular alkaline proteases from Streptomyces corchorusii ST36," Canadian Journal of Microbiology, vol. 41, no. 1, pp. 99-104, 1995.

[24] D. Cowan, R. Daniel, and H. Morgan, "Thermophilic proteases: properties and potential applications," Trends in Biotechnology, vol. 3, no. 3, pp. 68-72, 1985.

[25] P. Sampath, C. Subramanian, and G. Chandrakasan, "Extracellular proteases from streptomyces spp. G157: purification and 
characterization," Biotechnology and Applied Biochemistry, vol. 26, no. 2, pp. 85-90, 1997.

[26] M. Trop and Y. Birk, “The specificity of proteinases from Streptomyces griseus (pronase)," Biochemical Journal, vol. 116, no. 1, pp. 19-25, 1970.

[27] B. K. Bajaj and P. Sharma, "An alkali-thermotolerant extracellular protease from a newly isolated Streptomyces sp. DP2," New Biotechnology, vol. 28, no. 6, pp. 725-732, 2011.

[28] H. Lazim, H. Mankai, N. Slama, I. Barkallah, and F. Limam, "Production and optimization of thermophilic alkaline protease in solid-state fermentation by Streptomyces sp. CN902," Journal of Industrial Microbiology and Biotechnology, vol. 36, no. 4, pp. 531-537, 2009.

[29] D. Patke and S. Dey, "Proteolytic activity from a thermophilic Streptomyces megasporus strain SDP4," Letters in Applied Microbiology, vol. 26, no. 3, pp. 171-174, 1998.

[30] W. Aretz, K. P. Koller, and G. Riess, "Proteolytic enzymes from recombinant Streptomyces lividans TK24," FEMS Microbiology Letters, vol. 65, no. 1-2, pp. 31-35, 1989.

[31] N. S. Demina and S. V. Lysenko, "Exoproteases of Streptomyces lavendulae," Microbiology, vol. 64, no. 4, pp. 385-387, 1995.

[32] V. Bascarán, C. Hardisson, and A. F. Braña, "Regulation of extracellular protease production in Streptomyces clavuligerus," Applied Microbiology and Biotechnology, vol. 34, no. 2, pp. 208213, 1990.

[33] L. A. I. de Azeredo, M. B. de Lima, R. R. R. Coelho, and D. M. G. Freire, "A low-cost fermentation medium for thermophilic protease production by Streptomyces sp. 594 using feather meal and corn steep liquor," Current Microbiology, vol. 53, no. 4, pp. 335-339, 2006.

[34] M. J. North, "Comparative biochemistry of the proteinases of eucaryotic microorganisms," Microbiological Reviews, vol. 46, no. 3, pp. 308-340, 1982.

[35] R. Oberoi, Q. K. Beg, S. Puri, R. K. Saxena, and R. Gupta, "Characterization and wash performance analysis of an SDSstable alkaline protease from a Bacillus sp," World Journal of Microbiology and Biotechnology, vol. 17, no. 5, pp. 493-497, 2001.

[36] R. Gupta, K. Gupta, R. K. Saxena, and S. Khan, "Bleach-stable, alkaline protease from Bacillus sp," Biotechnology Letters, vol. 21, no. 2, pp. 135-138, 1999.

[37] J. Singh, N. Batra, and R. C. Sobti, "Serine alkaline protease from a newly isolated Bacillus sp. SSR1," Process Biochemistry, vol. 36, no. 8-9, pp. 781-785, 2001.

[38] S. H. Bhosale, M. B. Rao, V. V. Deshpande, and M. C. Srinivasan, "Thermostability of high-activity alkaline protease from Conidiobolus coronatus (NCL 86.8.20)," Enzyme and Microbial Technology, vol. 17, no. 2, pp. 136-139, 1995. 

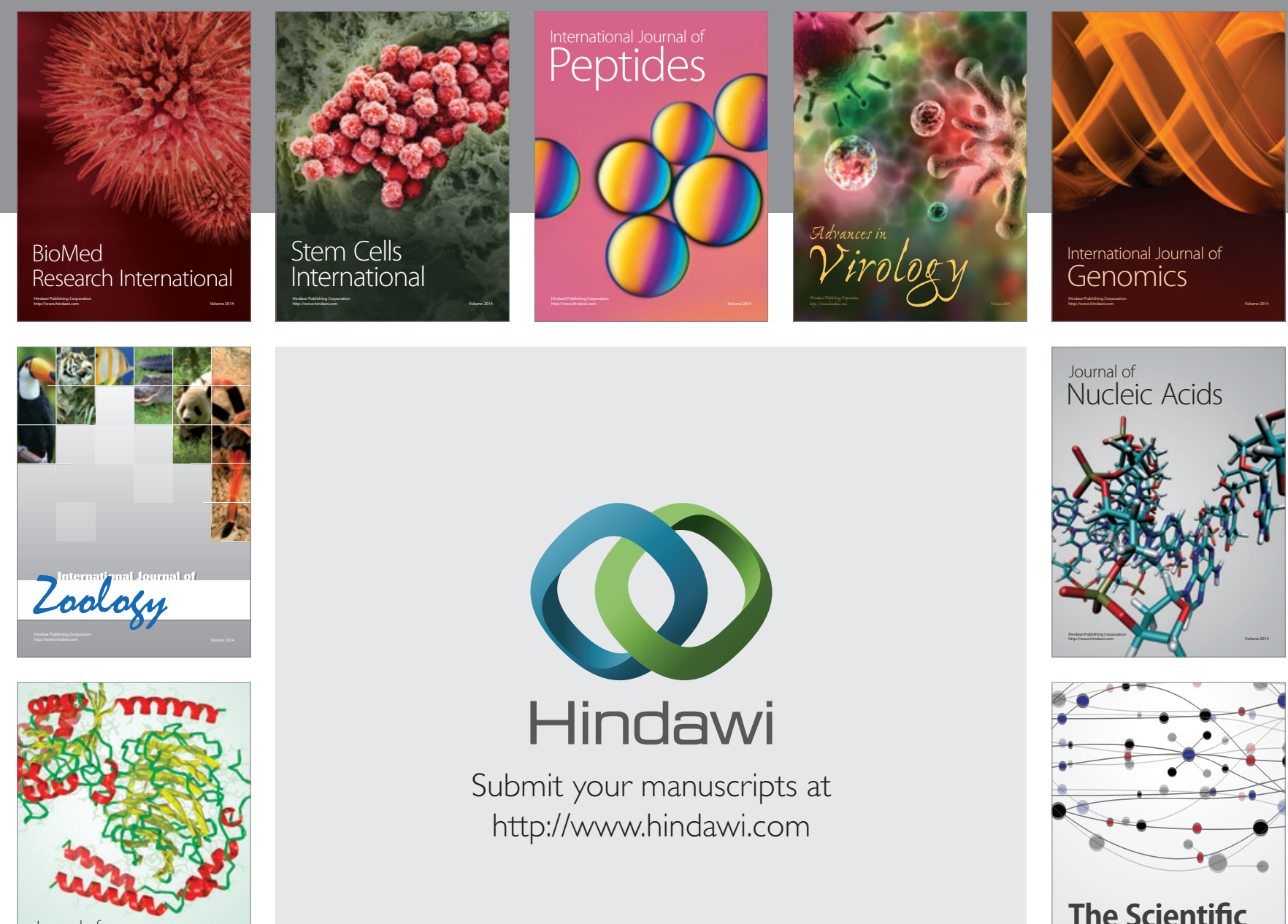

Submit your manuscripts at

http://www.hindawi.com

Journal of
Signal Transduction
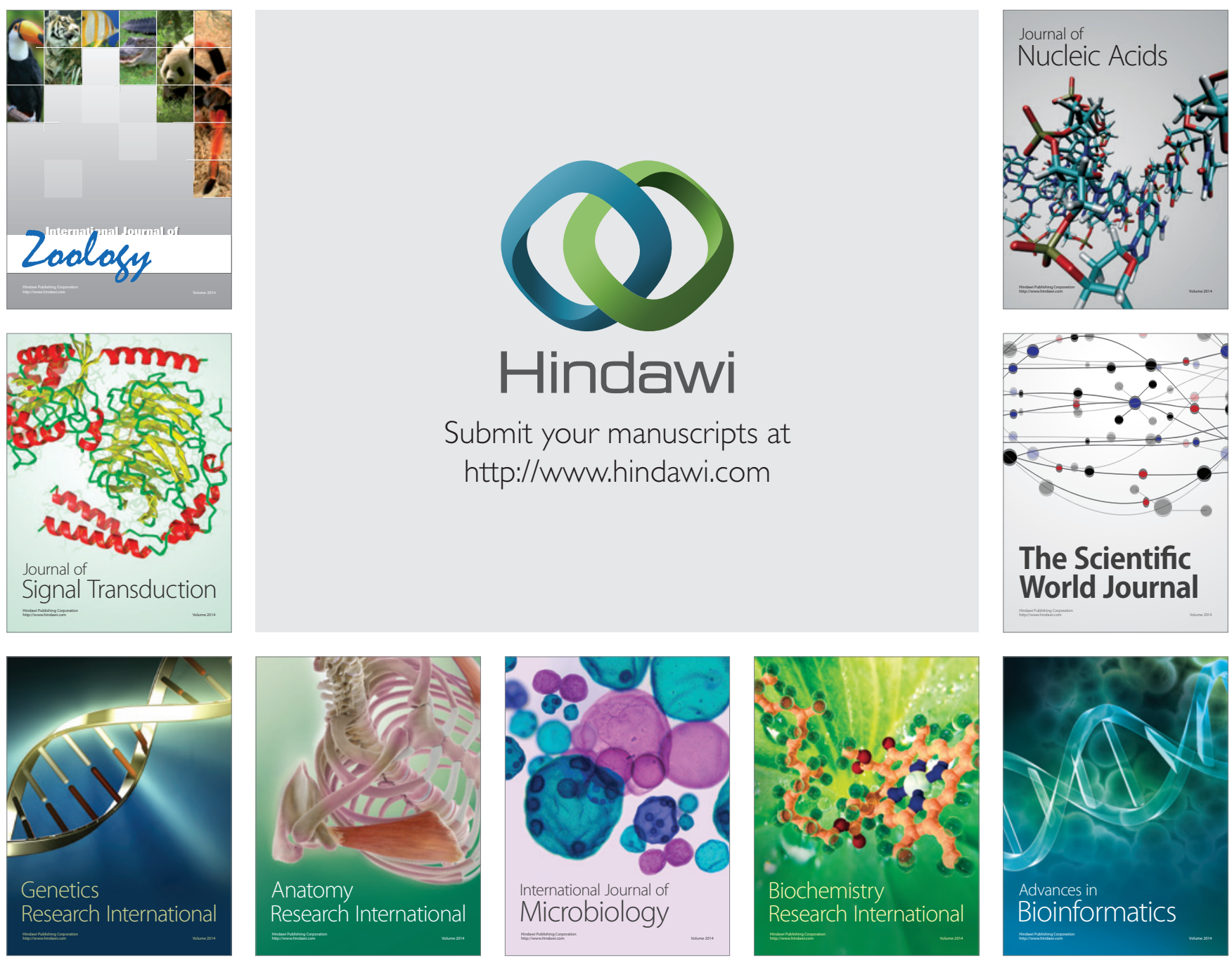

The Scientific World Journal
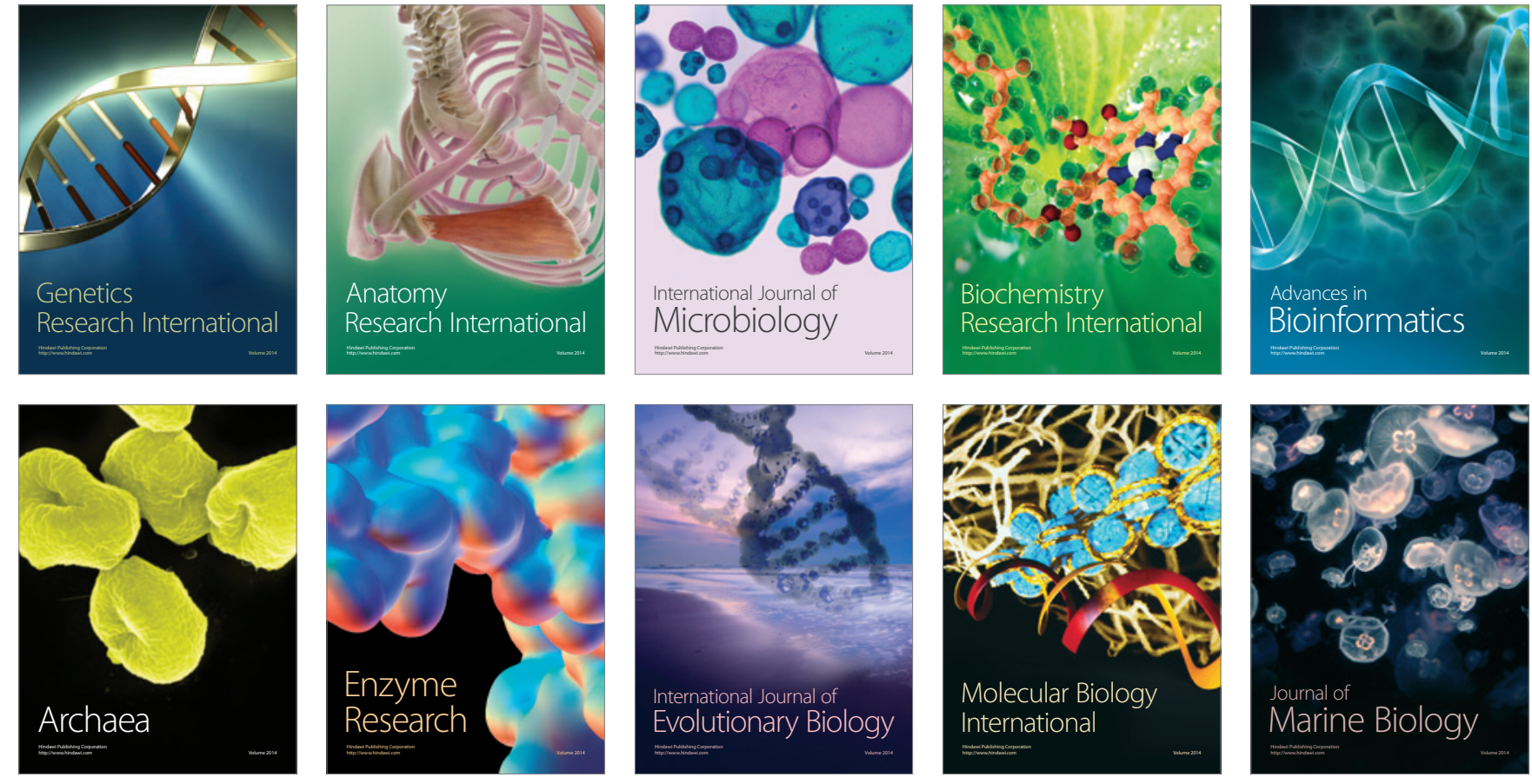